\title{
Population density of Saguinus leucopus (Mammalia: Primates) and landscape characteristics in eastern Antioquia, Colombia
}

\author{
William Yezid Bonell Rojas ${ }^{*}$, Mario Alberto Alvarez Rincon ${ }^{1}$ and Néstor Javier Roncancio Duque². \\ ${ }^{1}$ Wildlife Conservation Society - Colombia. Calle 31 bis No. 26b-51 sur. Bogotá, Colombia. Email: wbonell@hotmail.com (WYBR), \\ m03alvarez@gmail.com (MAAR). \\ ${ }_{2}^{2}$ Parques Nacionales Naturales de Colombia, Dirección Territorial Andes Occidentales. Email: nroncanciod@gmail.com (NJRD). \\ * Corresponding author.
}

Saguinus leucopus is an endemic primate of Colombia, listed as an "Endangered" species by IUCN because of its restricted distribution range in areas with intense colonization activity. Population density is a key factor in understanding the trends of $S$. leucopus populations after disturbance by the anthropogenic transformations of the landscape. Density is determined by its carrying capacity, being a dynamic parameter that varies in time and space. The trends in certain populations are inconclusive, as assessments were performed just one in a few sites. Besides, knowing the variables that govern the changes in population size as well as its regulation is important, starting with an empirical estimate of the number of individuals in populations. The objectives of this study were to estimate the population density of S. leucopus and determine its relationship with plant diversity and landscape characteristics. This study was developed in a forest, located in the municipality of San Rafael, Antioquia. The population density of S. leucopus was estimated using the distance-sampling method with linear transects; data were processed with the program DISTANCE 6.0. The physical features, structure and diversity of plant communities were also determined. The estimated population density of S. leucopus was 46.5 individuals $/ \mathrm{km}^{2}$ and $12.3 \mathrm{groups} / \mathrm{km}^{2}$, with coefficients of variation of $19.2 \%$ and $16.8 \%$, respectively. The component with the major contribution to the variance of density was the encounter rate, with $64.7 \%$. The study area is an open forest with moderate connectivity and a tendency to be circular; the vegetation cover is relatively homogeneous, being in the same stage of natural regeneration across its area. The estimated population density of S. leucopus is within the average reported for the species. Populations of S. leucopus tend to vary significantly according to the particular features of the local environment. In order to estimate the conservation status of the species through the analysis of variations in population density, this type of work should be linked to a monitoring strategy. In the study area, human activities over time have been key in determining the structure of the current vegetation. The population studied meets all the requirements to be in a good condition, since the continuous forest is protected and artificial structures built on-site allow the white-footed tamarin to forage and move; thus, it can be inferred that local populations inhabiting the study area are not isolated.

Saguinus leucopus es un primate endémico de Colombia, declarado como especie "En Peligro" por la IUCN porque su rango de distribución es restringido y se encuentra en áreas con alta actividad de colonización. La densidad poblacional es un factor importante para entender las tendencias de las poblaciones de S. leucopus después de ser perturbadas por las transformaciones del paisaje. La densidad está determinada por su capacidad de carga y es un parámetro dinámico que varía en el tiempo y en el espacio; con una evaluación realizada en pocos sitios en un momento en el tiempo, no se puede ser concluyente acerca de las tendencias que pueden seguir ciertas poblaciones. Es importante conocer los factores que determinan los cambios en el tamaño poblacional y los procesos que rigen su regulación, comenzando con una estimación empírica del número de individuos en las poblaciones. El objetivo de este trabajo fue estimar la densidad poblacional de $S$. leucopus y determinar su relación con la diversidad vegetal y características del paisaje. Este estudio se desarrolló en un bosque ubicado en el municipio de San Rafael, Antioquia. Para estimar la densidad poblacional de S. leucopus se usó el método de muestreo por distancias con transectos lineales. Los datos se usaron para estimar la densidad poblacional de S. leucopus utilizando el programa DISTANCE 6.0. Se determinaron características físicas y de estructura y diversidad vegetal. La densidad poblacional estimada de S. leucopus fue de 46.5 individuos $/ \mathrm{km}^{2}$ y 12.3 grupos $/ \mathrm{km}^{2}$, con coeficientes de variación del $19.2 \%$ y $16.8 \%$ respectivamente. El componente que más aportó a la varianza de la densidad fue la tasa de encuentro en un $64.7 \%$. El área de estudio es un bosque abierto con conectividad media y tendencia a ser circular, presentando homogeneidad en la cobertura vegetal con la mayoría de sus zonas en la misma etapa de regeneración natural. La densidad poblacional de $S$. leucopus obtenida se considera la media para la especie. Las poblaciones de S. leucopus tienden a presentar cambios significativos de acuerdo a las especificidades del ambiente. Para determinar el estado de conservación de la especie a través del análisis de las variaciones de la densidad poblacional, es necesario que este tipo de trabajos estén vinculados a un plan de monitoreo. Es probable que, en el área, actividades humanas que se han realizado a lo largo del tiempo, hayan determinado la estructura de la vegetación actual. La población estudiada, tiene las condiciones necesarias para encontrarse en buen estado, gracias a que el bosque continuo está protegido y las estructuras artificiales que allí se encuentran permiten al tití gris forrajear y desplazarse, así, se puede inferir que los grupos del área estudiada no se encuentran aislados.

Keywords: conservation; endemic; fragmentation; linear transects; populations; threats.

C 2018 Asociación Mexicana de Mastozoología, www.mastozoologiamexicana.org

\section{Introduction}

The loss of forest cover leads to population decline and even the disappearance of animal species that depend on these; the viability of populations in fragmented forests is often uncertain and varies widely between species (Irwin
2008). Primates play a key role in seed dispersal in tropical forests, where they contribute to the maintenance of plant diversity (Defler 2010).

An inadequate size of forest fragments disturbs the environmental offer and may result in the local extinction 
of certain primate species (Lovejoy et al. 1986; Schwarzkopf and Rylands 1989; Estrada and Coates-Estrada 1996; Chiarello 2000). In some relict forests, primate densities can be very high, but these are only the result of the temporary clustering of groups in increasingly smaller fragments (Link et al. 2010). However, the fact that they are not present in all fragments suggests that the fate of these populations is local extinction (Link et al. 2010).

Population density is a core element to understand trends in the populations of primates that have been disturbed by landscape transformations (Crockett and Eisenberg 1987). This makes necessary to assess other aspects such as group size and composition, as both are key elements in the dynamics that influence this demographic parameter (Crockett and Eisenberg 1987). The data on group size, population density, age and sex composition, collected over extended periods of time, can provide essential information to understand the tolerance to the loss and transformation of the habitat of a species (Estrada et al. 1994; Estrada and Coates-Estrada 1996; Crockett 1998; Cuaron 2000). Population density is determined by its carrying capacity, being a dynamic parameter that varies in time and space; therefore, it is important to bear in mind that an assessment derived from a few places at in a specific point in time cannot be conclusive about the trends in certain populations (Coulson et al. 2001; Rudran and Fernández-Duque 2003).

In some cases, due to the reduction and fragmentation of the habitat, some populations are forced to concentrate in a small space to the interior of fragments. This phenomenon, known as crowding, would explain the high densities of primates in landscapes with these characteristics (Defler 1981). This in turn increases competition and inbreeding, makes them vulnerable to predation and parasites, and results in lower reproduction and survival rates (Begon et al. 2006). In addition, the reduction of the habitat leads to increased parasite transmission (animal-animal), associated with the ability of parasites to be transmitted, reproduced and withstand environmental stress and the immune response of the host, thereby affect its birth and mortality rates (Nunn and Altizer 2006; Delahay et al. 2009; Roncancio and Benavides 2013). By modifying the distribution and abundance of individuals in natural landscapes, environmental disruption can affect the patterns of intraspecific competition (Días et al. 2011). Therefore, from the management and conservation perspectives, it is important to know the factors that determine changes in population size and the processes that regulate these changes. This knowledge must begin with an empirical estimate of the number of individuals in populations. However, in terms of knowledge of the ecological relationship of a population with its environment, local density is more revealing than total population size because the former is more directly related to ecological interactions at the local level (Ricklefs 2001). Habitat loss and environmental degradation are, to a large extent, the most important threats to primates in Colombia. Hunting and poaching for the pet market cause a relatively minor impact in areas with habitats that are still intact or where the natural populations of these species are relatively healthy (Defler 2010).

Saguinus leucopus is a primate endemic to Colombia, located in the Departments of Tolima, Caldas, Antioquia and Bolivar, in the central Andean region, at altitudes up to 1,500 meters above sea level (Defler 2010); these regions have undergone a significant amount of habitat as a consequence of human activities (Defler 2010). Saguinus leucopus was originally distributed in an area of approximately $49,000 \mathrm{~km}^{2}$. Due to the reduction and fragmentation of its habitat, it is estimated that this species has lost approximately $60 \%$ of this original distribution (Roncancio et al. 2013). Some studies have estimated the population density of Saguinus leucopus, ranging from 6 individuals $/ \mathrm{km}^{2}$ and 2 groups $/ \mathrm{km}^{2}$ (Mejía and Gomez 2011), up to 149 individuals $/ \mathrm{km}^{2}$ and 27 groups $/ \mathrm{km}^{2}$ (Roncancio et al. 2009).

Saguinus leucopus has been listed as an endangered species in Colombia due to its restricted range and the progressive destruction of its habitat, as it inhabits areas subjected to high human colonization (Morales-Jimenez et al. 2008a, b). In addition, many individuals are removed from their natural environment due to illegal trafficking to be marketed as pets (Defler 2010). This species is included in Appendix I of CITES (2017) and is listed as "Endangered" according to the IUCN (Morales-Jimenez et al. 2008b). Furthermore, it is included in the "Vulnerable" category at a national level (MADS 2017). Some researchers consider that this primate is seriously endangered of extinction due to its low genetic variability as a result of the isolation between populations (Leguizamón Hernández et al. 2006).

Saguinus leucopus is a small primate with a body length between 230 and $250 \mathrm{~mm}$, a mean tail length of $380 \mathrm{~mm}$ and a weight of about $460 \mathrm{~g}$ (Defler 2010). Groups usually include 3 to 9 individuals, although solitary animals or temporary associations of 14 or more individuals have been occassionally observed (Defler 2010). These animals, as well as other species of the genus, consume mainly soft fruits and insects, although their diet includes also lizards, snakes, frogs, birds, spiders, centipedes, millipedes, honey, bark, flowers, leaves, petioles, nectar, exudates and fungi (Cuartas-Calle 2004; Rodríguez-M. et al. 2006). It is a diurnal and arboreal species, moving across the forest using its arms and legs, and is able to jump between tree branches (Leal 2004), often using the lower and middle canopy (Green 1978).

The scarce information about the response of this species to processes such as habitat fragmentation and loss, makes necessary to collect data as part of a monitoring program aimed at determining the true status of the species. Whether mixed landscapes allow it to survive under normal conditions, and whether reserves are effective at maintaining viable populations of the species under the current characteristics and management approaches (Roncancio 2009).

Seeking to contribute to set a baseline to provide relevant information to protect the remaining populations of 
this primate, as well as reduce the current threats it faces. The objective of this work was to estimate the population density of S. leucopus in the Playas de San Rafael forest, located in eastern Antioquia, Colombia, and, from these results, compare the density obtained here with other localities, determine the association of population density with the local plant structure and diversity, and determine the physical characteristics of the study area.

\section{Materials and Methods}

Study area. The fieldwork for this study was carried out between July and September 2011 in the forest known as Playas de San Rafael, located in the vicinity of the Playas Hydroelectric Plant (6॰ 16' 48.936" N, -74 55' 47.136" W), owned by Empresas Públicas de Medellín, in the municipality of San Rafael, Department of Antioquia (Figure 1). The area is located in the eastern slopes of the Cordillera Central, on the left bank of the Magdalena river, between 900 and 1,200 meters above sea level; the local topography is undulating with moderate slopes (EPM 2011). The mean annual temperature in the area is $23.2^{\circ} \mathrm{C}$, and precipitation is $2,933 \mathrm{~mm} /$ year (Hijmans et al. 2005).

The forest stretches across approximately 3,875 ha, with 17 ha corresponding to forest plantations of Eucalyptus sp., and Pinus oocarpa, while 3,061 ha are covered by natural forests under a regeneration process during the past 30 years, aimed at preserving natural resources (EPM 2011). The vegetation type is classified as Premontane Wet Forest (bmh-PM; Holdridge 1967). This work was carried out in an area of 400 ha of natural forests.

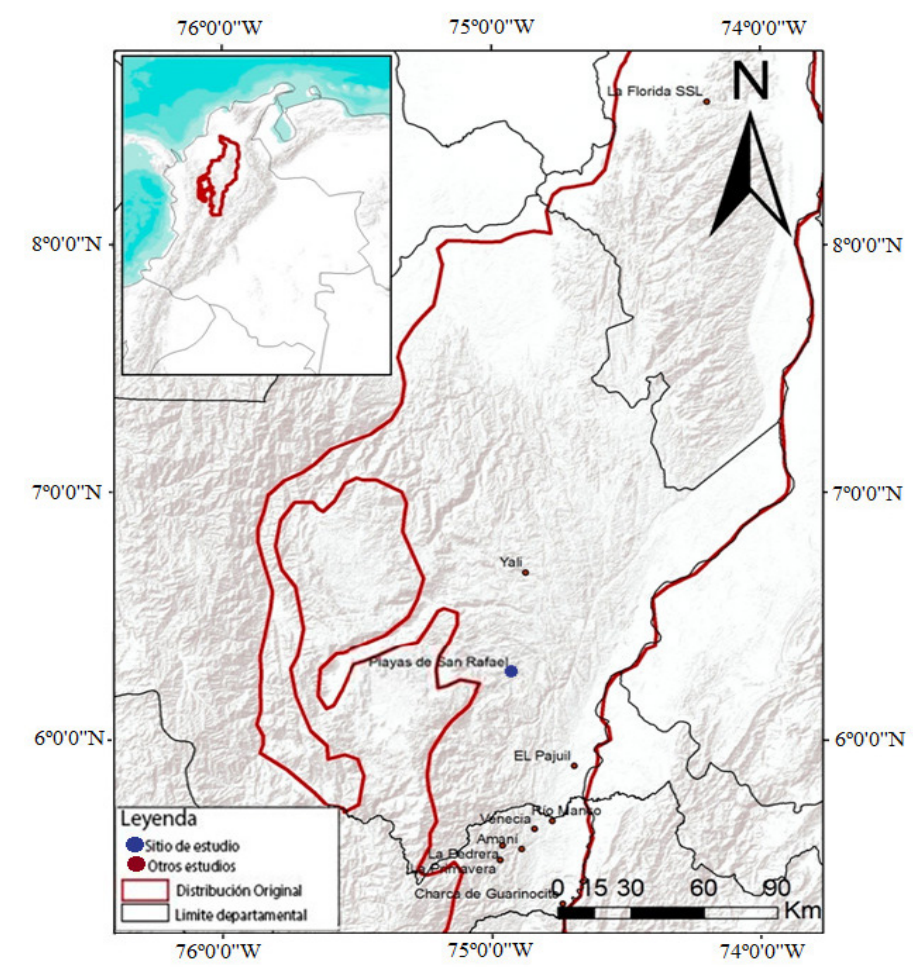

Figure 1. Localities with population density estimation for Saguinus leucopus. Amani (Santamaría et al. 2007), La Primavera (Pyritz et al. 2009), Charca de Guarinocito, El Pajuil, La Pedrera, Río Manso, Venecia (Roncancio et al. 2011), Yali - El Limón (Mejía and Gomez 2011), La Florida (Roncancio et al. In prep.) and Playas de San Rafael (this study).
Physical characteristics of the study area. In order to determine the physical characteristics of the area, a circle shaped local landscape of analysis was defined in the study site that should include, within the smallest perimeter, all the transects used to estimate the population density of S. leucopus. The circle was overlapped with a layer of land coverage in raster format with the Corine Land Cover methodology adapted for Colombia, at 1:100,000 scale (IDEAM 2010) and a digital elevation model. Five characteristics of the study area were measured in this local landscape: vegetation cover; mean shape index (MSI) obtained from the average of the relationship between the perimeter and area of patches. Interpersion juxtaposition index (IJI) on which the estimate of population density for S. leucopus was focused, being a value that measures the spatial combination of different types of fragments and is represented as a percentage of the maximum possible. Mean altitude above sea level, and weighted cover index (WCI). The weighted cover index was developed to incorporate an index to measure the composition and structure of vegetation cover in the local landscape. To estimate the WCl, the types of land cover were scored according to the following scale: dense forest $=8$, open forest $=7$, fragmented forest $=$ 6 , shrubland $=5$, herbaceous $=4$, crops $=3$, pasture $=2$, and bare soil, wetlands and urbanized areas $=1$. Then, the value of each type of land cover found in the local landscape was multiplied by its relative area; finally, the resulting figures were added up. In this way, if the WCl of a given landscape was about eight, the land cover tended to be dense forest; if, on the contrary, its value ranged between two and three, the local landscape was composed primarily of pastures and crops. All the analyzes were performed using the tool Patch Grid of ArcGis 9.3 (ESRI 2008).

Plant structure and diversity. The plant structure and diversity were assessed according to Roncancio et al. 2011, in six vegetation plots located randomly on some of the transects in the study area; each plot included an area of $50 \times 4 \mathrm{~m}$, for a total of $1,200 \mathrm{~m}^{2}(0.12 \mathrm{ha})$. In each plot, trees with a diameter at breast height $(\mathrm{DBH})>10 \mathrm{~cm}$ and height $>1.5 \mathrm{~m}$ were selected, these values were recorded and plant material was collected as reference for subsequent taxonomic identification by specialists in the Herbarium at the University of Caldas (Manizales, Colombia). The plant diversity analysis was conducted using the inverse Simpson index calculated with the program EstimateS 9.1 (Colwell et al. 2012).

Estimated population density and group size. The population density of S. leucopus was estimated using the sampling method by distances with linear transects and a single observer (Peres 1999; Buckland et al. 2001). This method involves counting the animals seen by an observer who walks along a transect line, by measuring the perpendicular distance to the point where the individual was observed or to the geographical center of the group observed (Peres 1999; Buckland et al. 2001). This methodology assumes the following: 1) The animals found at zero meters of distance perpendicular to the transect are always detected, i. e., the 
probability of detection is equal to 1.2 ) the animals in a group should be recorded in the position in which they were first observed, avoiding to count individuals more than once. 3) the distance between the line and the center of the group should be accurately measured. 4) all observations should be independent events.

To locate the transects, we walked around the whole edge of the study area, in order to determine the geolocation of the perimeter. The location of transects was designed aided with Geographic Information Systems (Figure 2). Forty-four transects were laid out systematically with an average length of $308.6 \mathrm{~m}$ ( $\mathrm{DS} \pm 27.6 \mathrm{~m}$ ), separated by $200 \mathrm{~m}$ between them, and arranged in a north-south direction at $180^{\circ}$; the total length of transects was $13.6 \mathrm{~km}$ and each was marked with phosphorescent tape every 20 $\mathrm{m}$. Each transect was walked in silence 8.1 times on average, at a mean speed of $0.6 \mathrm{~km} / \mathrm{h}$, with an average distance of $2.5 \mathrm{~km}$ per transect; this resulted in a cumulative sampling effort of $109.8 \mathrm{~km}$ away.

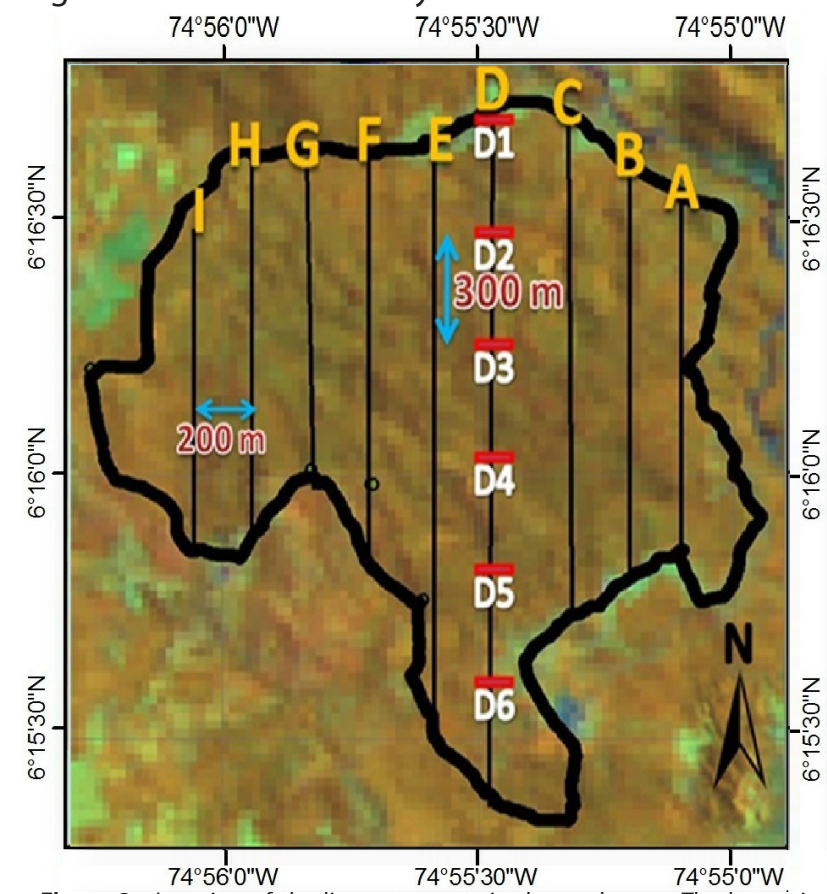

Figure 2. Location of the linear transects in the study area. The letters indicate the trails. ${ }^{*}$ Transects by trail (transects): Trail A: 4 transects, Trail B: 5 transects, Trail C: 6 transects, Trail D: 6 transects, Trail E: 6 transects, Trail F: 6 transects, Trail G: 4 transects, Trail $\mathrm{H}: 4$ transects, Trail I: 3 transects.

Tours were conducted by three persons walking simultaneously along different transects, from 7:00 until 12:00 hours and then from 14:00 to 16:30 hours. When a 20-minute tour was completed, 20 minutes passed before another started, assuming that this time was sufficient for groups of primates to be distributed "naturally" in the area, hence allowing to record the same group in a different transect according to the methodology.

Once an individual or group of S. leucopus was located, the observer remained on site a maximum of 15 minutes in order to keep a constant probability of detection along the transect (Peres 1999). This time is considered as sufficient to determine the size of the group, although there is the possibility of underestimating its size if groups are not followed. Once a group was detected, individuals were counted, measuring the distance perpendicular to the transect (from the geographical center of the group), and the geolocation of the record was determined. This information allowed determining the size of each group recorded; however, it was not possible to determine the sex and age composition, as this would require capturing and examining individuals.

Data Analysis. The DBH and height of vegetation were evaluated using average values; the density of trees was estimated projecting the number of individuals who met the characteristics for the analysis and that were collected (Roncancio et al. 2011). The inverted Simpson index was obtained with the program EstimateS 9.1 (Colwell et al. 2012) from a database of the species identified in each plot sampled, aiming to quantify the plant diversity in the study area.

The population density of $S$. leucopus was estimated with the program DISTANCE 6. 0 (Thomas et al. 2010). The analysis was run with a database containing transects, total sampling effort for each transect, perpendicular distance for each observation of individuals or groups, and number of individuals recorded in each observation. The aim of the distance sampling analysis is to fit a function to the detection of perpendicular distances of observations and use this function to estimate the proportion of primates that were not detected in the sampling (Thomas et al. 2002).

To find the detection function with the best fit, the frequency distribution of perpendicular distances was compared with six models: 1) Half normal with a cosine series expansion. 2) Half normal with Hermite polynomial. 3) Even with cosine. 4) Even with simple polynomial. 5) Hazard-rate with simple polynomial. 6) Hazard-rate with simple polynomial. From the above models, the one that yielded the lowest value in the Akaike information criterion (AIC) was selected. AIC is a quantitative method for the selection of the model that best fits the data and that uses the lowest number of parameters (Buckland et al. 2001).

The estimated population density for S. leucopus in the study area was compared with estimates for other localities by means of confidence intervals $(\mathrm{Cl})$. When the $\mathrm{Cls}$ of two density estimates showed an overlap greater than $25 \%$, it was considered that there was no evidence that the densities in both sites were significantly different, with a $95 \%$ confidence level (Cumming et al. 2007).

\section{Results}

Physical characteristics. The perimeter of the study area was $7.96 \mathrm{~km}$, bordering an area of $4.0 \mathrm{~km}^{2}$ (400 ha). The altitude was 1,003 meters above sea level; the weighted cover index () was 6.91 , so that the local vegetation can be regarded as an open forest; interpersion juxtaposition interpersion index (IJ) was 59.55, indicating a moderate degree of connectivity in the dominant cover; and the mean shape index (MSI) was 1.46 , indicating that the study area tends to be either circular or square. 
Plant structure and diversity. The area is dominated by trees of the families Hypericaceae, Melastomataceae, Urticaceae, Ochnaceae, Verbenaceae and Myrsinaceae. Also recorded were species of the families Annonaceae, Sapotaceae, Moraceae, Bignoniaceae, Rubiaceae, Chloranthaceae, Leguminosae, Arecaceae and Flacourtiaceae. A total of 62 individuals were collected, leading to the identification of 22 species; the most abundant one was Vismia macrophylla (Hypericaceae), followed by Belluccia pentamera (Melastomataceae), Cecropia peltata (Urticaceae), Cespedesia spathulata (Ochnaceae), Myrsine guianensis (Myrsinaceae), Lippia sp. (Verbenaceae), and Miconia sp. (Melastomataceae).

In Playas de San Rafael, the mean tree height was $11.5 \mathrm{~m}$ (DS \pm 4.56; range: 1.8 to $24.5 \mathrm{~m}$ ), the mean DAP was $17 \mathrm{~cm}$ (DS \pm 7.57; range: 10 to $52.07 \mathrm{~cm}$ ), the inverted Simpson index was 10.33, and plant density was 516 trees/ha.

Population Density of Saguinus leucopus. A total of 356 tours were performed, distributed in 44 transects, with an average of 8.1 tours/transect (range: 8 to 9). In all, 55 records of $S$. leucopus were obtained during these tours. The encounter rate was 0.5 groups $/ \mathrm{km}$. The mean group size was 3.8 individuals (DS \pm 2.21 ; range: 1 to 10 individuals/group). The best fit for the frequency distribution of perpendicular distances was the uniform model with a cosine series expansion (Buckland et al. 2001).

The estimated population density of S. leucopus in Playas de San Rafael was $46.5 \mathrm{ind} / \mathrm{km}^{2}(95 \% \mathrm{Cl}=31.9$ to 67.9$)$ and 12.3 groups $/ \mathrm{km}^{2}(95 \% \mathrm{Cl}=8.8$ to 17.2$)$, with coefficients of variation of $19.2 \%$ and $16.8 \%$, respectively. The component that most contributed to the variance of population density was the encounter rate with $64.7 \%$, followed by group size with $23.2 \%$, and probability of detection with $12.1 \%$.

\section{Discussion}

As regards vegetation structure and its relationship with the density of the white-footed tamarin, two fundamental aspects were considered, namely DBH and tree height. The $\mathrm{DBH}$ recorded in Playas de San Rafael was low relative to those found in Charca de Guarinocito $(32.95 \mathrm{~cm})$, Rio Manso $(23.38 \mathrm{~cm})$, Venecia $(20.30 \mathrm{~cm})$ and El Paujil $(19.67 \mathrm{~cm}$; Roncancio et al. 2011). The average tree height in Playas de San Rafael $(11.50 \mathrm{~m})$ evidenced a preference of $S$. leucopus for lower and middle strata ( 5 to $10 \mathrm{~m}$ ) in the forest.

The vegetation cover was homogeneous across the study area, since most of the zones within it were in the same natural regeneration stage. The presence of two individuals of the family Sapotaceae (Pouteria sp.) corroborates the extent of disruption of the forest; most Pouteria species are sciophyte trees, i. e., they need shade in the early stages; in addition, they are long-lived trees and tend to be located on sites with already established vegetation (Finegan 1996). In our study, Pouteria sp.1 showed the largest DBH of the trees sampled, suggesting that they could be relicts of the original vegetation.
The white-footed tamarin usually feeds on a wide variety of fruits that include those produced in secondary forests in early succession stages, riparian forests and even introduced plants (Poveda and Sánchez-Palomino 2004; Santamaria et al. 2007). Within the family Melastomataceae, Bellucia pentamera and Miconia sp. showed a significant abundance; these species have a high productivity of soft fruits that are consumed by S. leucopus (2004 CuartasCalle). As Playas de San Rafael is an area with low plant diversity, the permanent food availability can be attributed to families like this. In addition, S. leucopus also consumes fruits of Myrsine guianensis, Cecropia peltata, Inga sp., Pouteria sp., and Rollinia sp. Cuartas-Calle (2004), which were all collected during this work.

The population density of S. leucopus in Playas de San Rafael $\left(46.5 \mathrm{ind} / \mathrm{km}^{2}\right)$ was no different from those reported for other localities, such as the area of influence of the Amani dam (Santamaria et al. 2007), where a population density of $54 \mathrm{ind} / \mathrm{km}^{2}$ was reported $(95 \% \mathrm{Cl}=35$ to $84 \mathrm{ind} /$ $\left.\mathrm{km}^{2}\right)$. El Pajuil, which recorded $37 \mathrm{ind} / \mathrm{km}^{2}(95 \% \mathrm{Cl}=22$ to $61 \mathrm{ind} / \mathrm{km}^{2}$; Roncancio et al. 2011). This may be due to the broad coefficients of variation of population density for these sites (> $10 \%)$; narrower confidence intervals allow the detection of significant differences in the density for different areas. This imprecision in the estimate of population density is influenced, to a greater extent, by the variation in the encounter rate, since there is a differential use of the habitat in some locations (Roncancio et al. 2011). To improve the accuracy of the population density estimator, the number of transects should be increased.

To note, similar to this study, in Amani and El Pajuil the size of groups was not estimated from accurate counts of groups; instead, population density was estimated from counts recorded during tours; thus, population density may be underestimated, as the groups found during tours were not followed, some individuals might not have been recorded (Roncancio et al. 2011).

Playas de San Rafael recorded a higher population density versus Yali - Lemon (Mejía and Gomez 2011), a locality with a reported population density of $6 \mathrm{ind} / \mathrm{km}^{2}(\mathrm{Cl} 3$ to 10 ind $/ \mathrm{km}^{2}$ ). By contrast, the population density at Playas de San Rafael was lower than the one estimated for La Pedrera, of $101 \mathrm{ind} / \mathrm{km}^{2}$ (Cl 58 to 177), Río Manso with $142 \mathrm{ind} / \mathrm{km}^{2}$ (103 to 196), Venecia with $125 \mathrm{ind} / \mathrm{km}^{2}$ (Cl 55 to 286; Roncancio et al. 2011), and La Primavera with 149 ind $/ \mathrm{km}^{2}$ (Cl 78 to 284; Roncancio et al. 2009). The low population density at Yali-Limón may be related to anthropogenic pressures due to the unprotected status of the forest (Mejía and Gomez 2011). On the other hand, the high population density observed in the localities mentioned above can be explained as a density-related compensation, where the extinction of species of larger primates may lead to more resources available for populations of S. leucopus, hence resulting in an increased carrying capacity (McArthur et al. 1972). This overcrowding may also be associated with a crowding phenomenon, where populations tend to be 
concentrated in forest remnants that act as shelter when habitats become fragmented (Defler 1981).

The population of S. leucopus found in Playas de San Rafael currently meets the conditions required to be considered as in good condition, mainly for being a protected continuous forest. Although there are some roads and buildings that can be considered as barriers, no forest segment is isolated. For some mammal species, this type of artificial structures are likely barriers that restrain displacement; however, in the study area S. leucopus makes good use of these structures and individuals are frequently observed foraging or moving using the taller trees, and sometimes electrical cables as well, to get across roads (pers. obs.). Therefore, it might be assumed that the groups of S. leucopus in the study area are not isolated from other groups and that there is a constant flow of individuals, which would ensure genetic variability; however, genetic studies are necessary to confirm this hypothesis.

In Playas de San Rafael, human activities that have taken place over time such as the construction of the hydroelectric plant and the military base at the highest spot of the forest, in addition to selective logging and poaching, have likely contributed to shape the current vegetation structure. When events of these sort occur, is put to the test the potential capacity of the system to fill the surface area or space available in the forest (Roncancio 2009). Taking into account that one of the main functions of this primate in an ecosystem is the dispersion of seeds, it might suggest that, if there is a greater diversity of plants, probably the diversity in food supply for the tamarins also is greater. However, although the plant diversity in Playas de San Rafael is low compared to other places such as Rio Manso (85.04), Venecia (27.13), La Pedrera (21.54) and El Paujil (14.38) (Roncancio et al. 2011), are some of the favorite plant species by individuals of Saguinus leucopus.

The estimate of the density of Saguinus leucopus in Playas deSan Rafael obtained was $46.5 \mathrm{ind} / \mathrm{km}^{2}$, an average density for the species, taking into account the densities found in other localities. However, it is important to understand that the populations of S. leucopus tend to have significant changes according to the specificities of the environment. To be able to accurately determine the conservation status of the species, through the analysis of the variations in population density, it is necessary that this type of work are constant and are linked to a monitoring plan that will allow to make inferences about the trends of their populations.

\section{Acknowledgments}

Researchers A. Acosta and L. García, who guided and supported all the moments of this research. To EPM, and workers of the hydroelectric Playas de San Rafael, for giving us the space to develop this work, in addition to its logistical and his great kindness. To G. Torres, for his collaboration in the field phase of this research. This work was carried out thanks to the financing of the Wildlife Conservation Soci- ety (WCS), Colombian Association of Zoos and Aquariums (ACOPAZOA) and the European Association of Zoos and Aquaria (EAZA).

\section{Literatura citada}

Begon, M., C. Townsend, AND J. HARper. (eds.). 2006. Ecology: From Individuals to Ecosystems. Blackwell Publishing. Oxford, United Kindom.

Buckland, S. T., D. R. Anderson, K. P. Burnham, J. L. LaAke, D. L. BORCHERS, AND L. THOMAS. 2001. Introduction to distance sampling: estimating abundance of biological populations. Oxford University Press. Oxford, United Kindom.

Chiarello, A. 2000. Density and population size of mammals in remnants of Brazilian Atlantic forest. Conservation Biology 14:1649-1657.

Cites: Convención sobre el Comercio Internacional de Especies Amenazadas de Fauna y Flora Silvestres. 2017. Appendices I, II and II. https://www.cites.org/eng/app/appendices.php. Última visita: 26/07/2017.

Colwell, R. K., A. Chao, N. J. Gotell, S.-Y. Lin, C. X. Mao, R. L. Chazdon, AND J. T. Longino. 2012. Models and estimators linking individual-based and sample-based rarefaction, extrapolation, and comparison of assemblages. Journal of Plant Ecology 5:3-21.

Coulson, T., E. A. Catchpole, S. D. Albon, B.T. Morgan, J. M. Pemberton, T. H. Clutton-Brock, M. J. Crawley, and B. T. Grenfell. 2001. Age, sex, density, winter weather, and population crashes in Soay Sheep. Science 292:1528-1531.

CROCKETt, C. 1998. Conservation biology of the genus Alouatta. International Journal Primatology 9:549-578.

CROCKETT, C., AND J. EISENBERG. 1987. Howlers: variations in group size and demography. Pp 54-68 in Primate Societies (Smuts, B., Cheney, D., Seyfarth, R., Wrangham, R. y T. Struhsaker, eds.). Chicago: The University of Chicago Press. Chicago, U. S. A.

CuARÓN, A. D. 2000. Effects of land-cover changes on mammals in a neotropical region: a modeling approach. Conservation Biology 146:1676-1692.

Cuartas-Calle, C. A. 2004. Distribución histórica y actual, uso del hábitat y estimación del estado de conservación de Saguinus leucopus tití gris en el área de la jurisdicción de Corantioquia Corporación Autónoma Regional del Centro de Antioquia. Informe presentado a Corantioquia (Corporación Autónoma Regional del Centro de Antioquia). Medellín, Colombia.

Cumming, G., F. Fidler, M. Leonard, P. Kalinowski, A. Christensen, A. Kleinig, J. Lo, N. Mcmenamin, And S. Wilson. 2007. Statistical reform in psychology: Is anything changing? Psychological Science 18:230-232.

Defler, T. R. 1981. The density of Alouatta seniculus in the Eastern Llanos of Colombia. Primates 22:564-569.

DEFLER, T. R. 2010. Historia natural de los primates colombianos, segunda edición. Universidad Nacional De Colombia. Bogotá, Colombia.

DelahaY, R. J., G. C. SMith, AND M. R. Hutchings. 2009. Management of disease in wild mammals. Edinburgh, United Kindom.

Dias, P. A., A. Rangel Negrín, and D. Canales Espinosa. 2011. La conservación de los primates en México. Consejo Veracruzano de Investigación Científica y Desarrollo Tecnológico. Veracruz, México. 
EPM: Empresas Públicas de Medellín. 2011. Importancia de los bosques para EPM y para la sociedad. EPM 5:64-89. Medellín, Colombia.

ESRI ${ }^{\circledR}$ ArcGIS Desktop: Release 9.3. Redlands, CA: Environmental Systems RESEARCH INSTITUTE. 2008. Copyright (c) 1999-2016. ESRI Inc.

Estrada, A., and R. Coates-Estrada. 1996. Tropical rain forest fragmentation and wild populations of primates at Los Tuxtlas, Mexico. International Journal Primatology 17:759-783.

Estrada, A., R. Coates-Estrada, and J. R. Merrit. 1994. Non-flying mammals and landscape changes in the tropical rain forest region of Los Tuxtlas, México. Ecography 17:229-241.

FineGAN, B. 1996. Pattern and process in neotropical secondary rain forest: the first 100 years of succession. Trend in Ecology and Evolution 11:119-124.

Green, K. 1978. Primate censuring in northern Colombia: a comparison of two techniques. Primates 19:537-550.

Hijmans, R. J., S. E. Cameron, J. L. Parra, P. G. Jones, and A. Jarvis. 2005. Very high resolution interpolated climate surfaces for global land areas. International 1978. Journal of Climatology 25:1965-1978.

HoldRIDGE, L. R. 1967. Life Zone Ecology. Tropical Science Center. San José, Costa Rica.

IDEAM: Instituto de Hidrología, Meteorología y Estudios Ambientales. 2010. Leyenda Nacional de Coberturas de la Tierra. Metodología CORINE Land Cover adaptada para Colombia Escala 1:100.000. Instituto de Hidrología, Meteorología y Estudios Ambientales. Bogotá, Colombia.

IRWIN, M. T. 2008. Diademed sifaka Propithecus diadema ranging and habitat use in continuous and fragmented forest: higher density but lower viability in fragments? Biotropica 40:231-240.

LeAL, A. M. 2004. Identificación de los patrones de comportamiento y conformación de un grupo social de Tití gris (Saguinus leucopus) en proceso de rehabilitación. Tesis de pregrado no publicada Universidad Distrital Francisco José De Caldas. Bogotá D.C. Colombia.

Leguizamón Hernández, N., M. Ruíz García, and M. Castillo. 2006. Aplicaciones de los análisis genético poblacionales a partir de genotipos multilocus y metodologías basadas en modelos Bayesianos para la conservación de la especie Saguinus leucopus. Revista Conservación Ex-Situ. Investigación para el manejo en cautiverio y conservación de la fauna silvestre 1:17-28.

Link, A., A. G. De Luna, F. Alfonso, P. Giraldo-Beltran, and F. Ramírez. 2010. Initial effects of fragmentation on the density of three neotropical primate species in two lowland forests of Colombia. Endangered Species Research 13: 41-50.

Lovejoy, T. E., R. O. Bierregaard, A. B. Rylands, J. R. Malcolm, C. E. Quintela, L. H. Harper, K. S. Brown JR, A. H. Powell, G. V. Powell, H. O. Schubart, And M. B. Hays. 1986. Edge and other effects of isolation on Amazon forest fragments. Pp. 257-285 in Conservation Biology: The science of scarcity and diversity (M. E. Soulé, ed.). Sinauer. Sunderland, U. S. A.

MADS: Ministerio de Ambiente y Desarrollo Sostenible. 2017. Resolución 1912 del 15 de septiembre de 2017.

McArthur, R., J. DiAmond, AND J. KaRR. 1972. Density Compensation in Island Faunas. Ecology 532:330-342.

Mejía, F. S., AND M. F. Gómez. 2011. Densidad poblacional de Saguinus leucopus tití gris en un fragmento de bosque en el nordeste de Antioquia. Tesis de pregrado no publicada. Universidad de Caldas. Manizales, Colombia.
Morales-Jiménez, A.L., A. Link, and P. Stevenson. 2008b. Saguinus leucopus. The IUCN Red List of Threatened Species 2008: e.T19819A9019454.

Morales-Jiménez, A. L., S. Vejarano Rivadeneira, C. L. Rodríguez, and O. Ospina Herrera. 2008a. Programa Nacional para la Conservación de la Especie Endémica de Colombia tití gris Saguinus leucopus. Ministerio de Ambiente, Vivienda y Desarrollo Territorial, Viceministerio de Ambiente. Bogotá, Colombia.

Nunn, C., And S. Altizer. 2006. Behavior, ecology and evolution. Pp. 85 in Infectious diseases in primates (Nunn, C., and S. Altizer, eds.). Oxford University Press. Nueva York, U. S. A.

PeRES, C. A. 1999. General guidelines for standardizing linetransect surveys of tropical forest primates. Neotropical Primates 7:1-16.

Poveda, K., And P. SÁnchez- Palomino. 2004. Habitat use by the white-footed tamarin, Saguinus leucopus: a comparison between a Forest-dwelling group and an urban group in Mariquita, Colombia. Neotropical Primates 121:6-9.

RICKLEFS, R. 2001. Invitación a la Ecología - La economía de la naturaleza, cuarta edición. Editorial Médica Panamericana, S. A.

Rodríguez-M., J. V., A. Rodríguez, and T. Defler. 2006. Titi gris Saguinus leucopus. Pp. 191 en Libro rojo de los mamíferos de Colombia. Serie libro rojos de especies amenazadas de Colombia (Rodríguez-M., J. V., M. Alberico, F. Trujillo, and J. Jorgenson, eds.). Conservación internacional Colombia \& Ministerio de Ambiente, Vivienda y Desarrollo Territorial. Bogotá, Colombia.

Roncancio, N. J. 2009. Densidad poblacional de Saguinus leucopus en áreas alteradas con diferentes características físicas y biológicas en el departamento de Caldas. Tesis de maestría no publicada. Universidad Nacional de Colombia. Bogotá, Colombia.

Roncancio, N. J., and J. A. Benavides Montaño. 2013. Parásitos intestinales en poblaciones pequeñas y aisladas de mono aullador rojo (Alouatta seniculus) y mono araña café (Ateles hybridus), Atelidae - Primates en el Magdalena Medio. Veterinaria y Zootecnia 7:71-89.

Roncancio, N. J., W. Rojas, and J. Esteves. 2009. Densidad poblacional y tamaño de grupo de Saguinus leucopus en parches de bosque en el departamento de Caldas, Colombia. Neotropical Primates 152:63-67.

Roncancio, N. J., W. Rojas, and T. Defler. 2011. Densidad poblacional de Saguinus leucopus en remanentes de bosque con diferentes características físicas y biológicas. Mastozoología Neotropical 18 1:105-117.

Roncancio, N. J., A. Castañeda, L. M. García, and C. A. Ríos. 2013. Distribución potencial y disponibilidad de hábitat actual del primate endémico de Colombia y en peligro de extinción titi gris (Saguinus leucopus). Pp. 217-243 in Primates Colombianos en Peligro de Extinción (Defler, T. R., P. R. Stevenson, M. L. Bueno, and D. C. Guzmán Caro, eds.). Asociación Primatológica Colombiana. Bogotá, Colombia.

Rudran, R., And E. Fernández-Dugue. 2003. Demographic changes over thirty years in a red howler population in Venezuela. International Journal of Primatology 24:925-947.

Santamaría, M., C. Devenís, A. M. Franco, J. D. Sánchez, H. Mendoza, C. Pedraza, F. Forero, and S. Medina. 2007. Densidad y ecología básica del tití gris Saguinus leucopus en el área de 
influencia del Embalse Amaní, Norcasia, Caldas. Manuscrito no publicado, Instituto Alexander Von Humboldt-ISAGEN. Bogotá, Colombia.

SCHWARZKopf, L., AND A. B. Rylands. 1989. Primate species richness in relation to habitat structure in Amazonian rainforest fragments. Biological Conservation 48:1-12.

Thomas, L., S. T. Buckland, K. P. Burnham, D. R. Anderson, J. L. LAake, D. L. Borchers, and S. StrindBerg. 2002. Distance Sampling. Pp. 544-552 en Encyclopedia of Environmetrics vol 1 (ElShaarawi, A. H., and W. W. Piegorsch, eds.). John Wiley y Sons, Ltd. Chichester, United Kindom.

Thomas, L., S. T. Buckland, E. A. ReXstad, J. L. Laake, S. Strindberg, S. L. Hedley, J. R. B. Bishop, T. A. Marques, and K. P. Burnham. 2010. Distance software: design and analysis of distance sampling surveys for estimating population size. Journal of Applied Ecology 47:5-14.

Associated editor: Rafael Avila

Submitted: August 9, 2017; Reviewed: August 31, 2017;

Accepted: January 24, 2018; Published on line: January 29, 2018. 